\title{
The Role of Forest Resources in the Performance of Community Forest Enterprise in Mexico: Analytical Framework from Competitive Strategy
}

\author{
J. Regino Maldonado1 $\&$, Yali Wen², Carpenter Christopher ${ }^{2}$
}

\author{
${ }^{1}$ School of Economics and Management, Beijing Forestry University, Beijing 100083, China. Instituto Politécnico \\ Nacional. México \\ ${ }^{2}$ School of Economics and Management, Beijing Forestry University, Beijing 100083, China
}

\begin{abstract}
The objective was to make an analytical framework to support the strategy and performance of the community forest enterprise. To do this, we used theoretical analysis of the contributions of the main theories of the firm. The new institutional economics the role of institutions in common were analyzed. The institutions of governance and property rights of the communities determine the organizational structure and incentives. The possibilities of exchange of production and efficiency of community forest enterprise. The enterprise aligns multiple objectives in the governance of the commons, and the strategy. Community forest enterprise's strategy is based on the use and control of forest resources and engages simultaneously in vertical integration in so far as they mature management skills and production in general. The analysis of the literature suggests that the performance of the community forest enterprise is positive because they are not only profitable domestic market, but also contribute to poverty reduction and environmental protection. However, it has implications as pressure on forest resources, overregulation of natural resources; individuals do not achieve the social optimum, and therefore high-risk domestic market and loss of competitiveness internationally.
\end{abstract}

Keywords: Common-pool resources; Vertical integration; New institutional economics; Theory of the firm; Resource-based view; Structural theory

\begin{abstract}
1. Introduction
Given the importance of forests to combat climate change, maintain ecosystem services and eradicate poverty, worldwide attention has turned to assessing sustainable forms of conservation and use of natural resources that respond to these global concerns. Mexico has about 65 million ha of forest cover which represents about $33 \%$ of the country. Of that there are $95 \%$ natural forests $(53 \%$ primary and $42 \%$ secondary), and only $5 \%$ planted forests (FAO, 2010). Of the total forest cover around $60 \%$ is social property (ejido land and communal land), where about 12 million people live, of which about $55 \%$ are in extreme poverty (Cubbage et al., 2013).
\end{abstract}

Thus, two-thirds of natural forests in Mexico are under the ownership of communities who have the right to use their natural resources. The transition from state-led to community-led agrarian governance in Mexico, stemming from the 1992 constitutional reforms, has only strengthened autonomy to devise locally optimal governance solutions (Bray et al., 2006). Thus the democratization of natural resources through land reform contributed to the expansion of the community forest sector in Mexico (Boyce and Shelly, 2003).

According to Segura (2014) in the country there are 15859 forest communities, of which 2380 manage their forests for commercial purposes. There are around 992 community forest enterprises (CFEs), according to their state from low to high vertical integration in the timber production are classified as type I, II, III and V; besides revenues for marketing wood also they have revenues from non-timber forest products, and a program of payment for environmental services, carbon sequestration, water capture or biodiversity (CONAFOR, 2013; Cubbage, 2013). These points are associated with the importance of forests in mitigating and adapting to climate change. Thus how the government and communities advance in achieving their goals of

This article is published under the terms of the Creative Commons Attribution License 4.0

Author(s) retain the copyright of this article. Publication rights with Alkhaer Publications.

Published at: http://www.ijsciences.com/pub/issue/2015-05/

Article Number: V4201505700; Online ISSN: 2305-3925; Print ISSN: 2410-4477 
sustainable development and objectives Millennium Development, in environmental conservation and poverty eradication.

Therefore the community forest enterprise (CFE) plays an important role in the economic, social and environmental development. Some studies have recognized its importance not only in Mexico but in Latin America as a whole (Bray et al., 2006; Cortave, 2003; Putz et al., 2004). In fact, the CFE has emerged and is evolving in other countries (Scherr, White and Kaimowitz, 2003; Nolan, 2001; Cortave, 2003); and there is a growing tendency to the return of forest land to local communities (White and Martin, 2002; McDaniel, 2003; Zhang et al., 2000; Shen et al., 2009).

In a literature review of the commons there are studies on the impact of land reform and forest laws in the formation of CFEs (Bray et al., 2006; Boyce and Shelly, 2003). Several studies show the involvement of the state in shaping institutions of the commons (White and Martin, 2002). While other studies focus on self-governance based institutions and how they have been determinant in the management of the commons (Ostrom, 1995; Agrawal and Gibson, 1999). Some studies also focus on social capital in the commons (Ahn and Ostrom, 2003; Bray et al., 2003; Krishna, 2000). However, there are few studies from the business perspective and competitive strategies of the CFE (Antinori and Bray, 2005; Antinori, 2000; Antinori, 2007; Cubbage et al, 2013; Villavicencio, 2012).

Antinori and Bray (2005) provide elements that show the differences between Mexican CFE and private forests in terms of governance and property rights. This is key to understanding the behavior and performance of the enterprises. Antinori (2007) notes that in long-term economic performance CFE is essential to maintain and expanding the market.

Therefore, in this first report corresponding to the first stage of a larger project on vertical integration and performance of the CFE in Mexico, the objective was to make an analytical framework that will base the strategy CFE and the key factors in their performance.

The analysis becomes relevant to a scenario where it is expected that the forest cover in Latin America continues to decline from 964 million ha in 2002 to 881 million ha in 2020 (FAO, 2006), and in a context of free trade and economic integration for the exchange between markets at different scales.

Competitive strategies have been adopted by some forest enterprises in Latin. Countries with an international market for forest products such as;
Brazil and Chile use lateral integration with different types of industry and the detriment vertical integration forest-industry. The lands emerged as an asset for different types of investors. The enterprises replaced natural trees by planted trees in the production. Tax incentives were promoted to plantations by states and they implemented strategies to attract foreign direct investment to their forestry sectors (FAO, 2006).

The analysis has been divided into 5 points, after the introduction as the first point, in the second point emergence CFE is addressed, the third point are the contributions and two models on performance enterprise are discussed. In the fourth point; performance of CFE in a vertical integration scheme it is investigated and the fifth point are the conclusions.

\section{Emergence of CFE}

In Mexico from the forties to early sixties the government promoted forest sawmills, which were forced to sell to a single buyer or dealer at a price established by it or by government institutions (Bray et al., 2004). Since then, the federal government has authorized concessions for forest exploitation parastatals and private companies, which left communities uncertain over the ownership and management of the forest. During the period 19741986 forestry in Mexican was characterized by turbulent political and governmental programs with many activist foresters. The expiring concessions parastatals and private companies that had granted the state originated communities initiated a fight for the rights of the forest. Several organizations emerged that proposed a restoration of the rights of the forest by the communities and for community forestry. This was an option other than public ownership and private interests (Merino and Segura, 2005). In Oaxaca, Mexico the Organización en Defensa de los Recursos Naturales y Desarrollo Social de la Sierra Juárez (ODRENASIJ for its acronym in Spanish), and other organizations developed (Chapela, 1995). The 1986 law ended all private concessions and began a process of dismantling the forest parastatals (Bray et al., 2006). Communities took control of forest resources and initiated the commercialization of timber at market prices (Bray et al., 2004).

In 1992 the reform of article 27 of the Mexican Constitution which regulated land ownership and provided return of control of forest resources to the local communities (Muñoz-Piña et al., 2003). The new agrarian law of 1992 established the land tenure for private, ejido and communal property. These last two tenures of land are known as social or communal property. The difference between them is that while the ejido property divisions can be made in private 
plots, dissolving the communal property is not possible (Ley, 2002). However, both ejidos and forest communities decided not to divide the land out into parcels and continue the unfragmented control of their forests. A first impact of the new agrarian law was the creation of forest enterprises known as "working groups" made up of individual landowners, under the legal category of Society of Rural Production (Wilshusen, 2003). The law also favored cutting activities, transport and processing of timber products. It promoted the private service foresters who gave technical assistance and forest management to communities with salaries paid to them enterprise instead of the state like before. It is important to say that since the new agrarian law of 1992 an incentive was given to commercial forest plantations (Bray et al., 2006; Segura, 2014).

The 1997 law had an objective to deregulate the management of natural forests and introduced support for community forestry. It also regulated and continued to promote incentives for commercial plantations. It created the Support Program for the Development of Commercial Forest Plantations (PRODEPLAN for its acronym in Spanish), and the Forest Development Program (PRODEFOR for its acronym in Spanish). The first program had as objective to develop productive projects, and the second to encourage the sustainable use of natural ecosystems. The Conservation and Sustainable Management of Forest Resources was created in 2001 (PROCYMAF for its acronym in Spanish), with the objective of promoting the strengthening of ejido and community organizations, as well as the construction and operation of CFEs. In 2009 the program increased its budget for more attention to communities; during this second stage it created the framework to build the type of CFEs according to the level of its organizational capacities for the management natural resources, capitalization and level of vertical integration in the chain of forest production (Segura, 2014). Type I enterprises are those that have forest resources but do not perform management activities, type II enterprises sell their stumpage, type III enterprises have some forestry units and sell their roundwood, and type IV are those enterprises that transform natural resources and add value to products (mills and factories). From 2011 PROCYMAF was renamed the Community Forestry Development Program (PDFC for its acronym in Spanish) whose program promotes technical training of forest advisors, processes of community organization and support to CFE (CONAFOR, 2012).

Thus the agrarian law of 1992 retained the forms of governance of the communities that were established during the Mexican Revolution, and were used to create CFEs (Antinori and Bray, 2005). According to Bray et al. (2006) currently there are at least three types of models for CFE in Mexico 1) CFE directly managed by the community government with traditional governance practices, 2) the community has created a clear division between corporate governance and community governance through community boards and administrators, and 3) the dissolution of the single model of CFE in subcommunal enterprise.

\section{Performance of the firm}

The strategy and competitive advantage of the firm's performance plays a fundamental role. Two models in dispute explain the performance of the firm, 1) the model of the resources based view (RBV) (Barney, 1991 ; 1986), and 2) the model of structuralist theory (ST) (Porter, 1985; 1980). The two previous theories are based on the analysis of the assumptions that are (ST) violated in the model of perfect competition or their failures. These strategic failures are considered beneficial to obtaining extra profits.

\subsection{Resources based view}

The RBV noted that internal factors explain the performance firm, which has its origins in the work of Penrose (1959) with the theory of the growth of the firm (Mahoney and Pandian, 1992). Two of such are the main contributions of Penrose works to RBV, 1) consider the firm as a comprehensive system of resources, and 2) consider that the optimal growth of the firm involves a balance between exploitation of existing resources and the development new products (Wernefelt, 1984). Penrose noted that a firm is a collection and accumulation of internal and external resources that contribute to its expansion.

In this line study, Barney (1991), the main promoter of the RBV explains about strategic resource contribution to obtain a superior performance against competitors, his an approach that rests on two assumptions: 1) the resources are heterogeneous firms, and thus the performance is also heterogeneous as reaching accumulate resources and control over a long period of time, 2) the resources are not moving, this means their impact and efficiency are a function of a given time and space. He also argues that resources must be valuable, rare, imperfectly imitable irreplaceable and to contribute to the superior performance and sustained competitive advantage of the firm.

This theory has been empirically supported by several studies to manufacturing enterprises in developed countries, which show that internal factors explain further the performance of the firm as compared to industry factors (Hawawini, Subramanian and Verdin, 2003; Mauri and Michaels, 1998; McGahan and Porter, 1997; Rumelt, 1991; Hansen and Wernelfelt, 1989); in particular there are studies that have looked at the importance of 
intangible resources, as part of the internal factors of the firm's performance (Miller, 2004; Schroeder, Bates and Junttila, 2002; Yli-Renko, Autio and Sapienza, 2001); and knowledge as the most impact on firm performance (Hatch and Dyer, 2004; McEvily and Chakravarthy, 2002; Grant, 1996; Hall, 1993; 1992; Brush and Changanti, 1998).

\subsection{Structuralist theory}

ST holds that the industry structure affects the performance of the firm. Early studies argued that the key factors in the performance were associated with high barriers to entry, number and size of firms in the industry, product differentiation, vertical integration and concentration of suppliers; allowing for the monopolistic practices (Bain, 1954). Emphasis was placed on the relationship of market power and profitability. Later studies showed the efficiency of industry structure in the performance of the firm (Rumelt et al., 1991; Schmalensee, 1985). Other studies showed that the size of the firm was associated with performance (Hall, and Weiss, 1967), while still others proved that the relationship between size and profitability was ambiguous (Prescott et al., 1986).

According Schmalensee and Willing (1992) studies in the field of economics industrial organization under the structure-conduct-performance model approach has been beneficial in advancing models of imperfect competition in which the violation each of the axioms of the neoclassical economic model is analyzed, or a combination of them to explain variations in performance. Among those who have made contributions are transaction costs theory (Williamson, 1975), evolutionary theory of the firm (Reinganum, 1989; in Schmalensee and Willing, 1992 ) theory of the firm (Holmstrom and Tirole, 1989; in Schmalensee and Willing, 1992) game theory (Fudenberg and Tirole, 1989; in Schmalensee and Willing, 1992). Models that analyze factors such as; uncertainty, information asymmetries, bounded rationality, opportunism, asset specificity, vertical and horizontal integration, price discrimination, product differentiation, incomplete contracts, and strategic decisions in static and dynamic games with or without cooperation, among others.

Clearly, the new economics industrial organization evolves from the contributions of the structureconduct-performance classic model. From this renewed field of study, some studies have attempted to model the forces of supply and demand operating in a given market of specific industries using data as time series, indices of market concentration, etc., some studies using methods for parametric studies (Corts, 1999; Berry, Levinsohn and Pakes, 1995; Bresnahan, 1989, in Coloma, 2002).

\section{Performance of CFE from the new institutional economics}

The new institutional economics (NIE) suggests that in a world of high transaction costs the institutions determined the possibilities of exchange, as the incentive structure and the level of efficiency of society; the latter being the motivating factor neoclassical economics (Coase, 1960; North, 1990). The economics of natural resources has recognized the importance of institutions in managing them (Pearce and Turner, 1990; Azqueta and Ferreiro, 1994). However it pointed out that for many years the institutional economics had focused on the study of property rights and lacked a comprehensive approach that successfully developed from empirical findings of the new institutionalists.

According to Clark (1990), the economics of natural resources has identified three issues regarding the use of natural resources, 1) free access to natural resources, 2) the problem of discounting of the future, and 3) uncertainty in the management of natural resources. It is in the first of the problems which the contributions of the new institutional economics become relevant, allowing for broader and deeper the role of institutions in managing natural resources comprehensive understanding. Further to the approach of the Tragedy of the Commons Hardin (1968), that under a system of open access to a common resource maximization by individuals, the use of benefits and ease of access leads to overexploitation of natural resources. Thus, the study of the commons is relevant for the analysis of open access regimes or common property and is key to understanding the importance of institutions and governance of natural resources (Ostrom, 1990).

\subsection{Common-pool resources and CFE}

Commons are resources that more than one person has access to, but where each person's consumption reduces availability of the resource to others and the most important examples include fish stocks, pastures and forests, and water for drinking or irrigation; on a larger scale, the air and the oceans are also commons resources (Ostrom, 1990).

Since the publication of the article the Tragedy of the Commons (Hardin, 1968), it was considered that this contribution captured the essence of the problem facing most common-pool resources in the world, since users are caught in the dilemma of getting greater benefit individually or to allow greater collective benefit; recommended that institutions establish outside authorities to govern such scenarios to avoid degradation of natural resources (Burger, Ostrom, Policansky, Norgaard and Goldstein, 2001). However, in societies with common-pool resources it requires the development of an institutional framework from which it is possible to manage 
natural resources and property rights (Ostrom, 1990). The NIE explains how organizations and individuals generate their own rules and regulations based on sanctions or awards related to the behavior of people.

For North (1990), institutions are the formal and informal rules that shape the behavior of individuals, organizations and mechanisms of compliance with those rules. Formal institutions are explicit as constitutions, laws, contracts, etc., while informal institutions are unwritten as codes of conduct, social, civic culture, ethical or religious issues.

Ostrom (1990) distinguishes the establishment of rules in communities with common-pool resources in three hierarchical levels: 1) operating rules, 2) rules of collective choice, and 3) constitutional election rules; which affect the actions taken and results of the community. On the first level are the processes of appropriation rules, provision and supervision; at the intermediate level is collective choice. This is including the processes related to the management and allocation policies; while at the highest level they are the constitutional rules. However, in a society that seeks to establish a regulatory framework under the three hierarchical levels mentioned above, it is necessary to establish a fundamental institution of property rights, which must be strict and well defined, so as to establish the conditions and scope about management of natural resources (Schlager and Ostrom, 1992).

According to Schlager and Ostrom (1992), property rights that largely determine the government of the commons are: access and extraction (rights of use), management, exclusion and alienation (control rights). In the case of alienation community forest owners have no right to sell the land, but can profit from flows of natural resources such as food, wood, and other ecosystem services. In addition Ostrom (1990) proposes eight principles of long-term common- pool resources that communities have adopted in the design and implementation of rules and regulations. These are: clearly defined boundaries, consistency between the rules of ownership and provision to local conditions, arrangements collective choice, monitoring, graduated sanctions, mechanisms for conflict resolution, minimum rights recognized organization, and resources that are part of larger systems, nested entities.

The property rights of community forest land in Mexico began with the Mexican Revolution and were consolidated with the agrarian reform (1934-1940). They were not completed until the early nineties as a result of the reform of article 27 of the Constitution and Agrarian Law of 1992; It was made explicit that community forest land should remain as commons lands, as inalienable (Segura, 2014). The new Constitution and law of 1992 establishes that communal land owners have the right of access and extraction of natural resources. However, the state retains control of forest management through various programs of natural resource management and regulation of forest technical services providers. The right to exclusion community forests is in the hands of community authorities, whose regulations define access, use and distribution of the flows of natural resources.

Overall the study of the commons has been developed in four lines, 1. Studies show where state involvement in shaping national and local institutions of the commons. In some countries a growing tendency to the return of forest land to local communities (White and Martin, 2002; Cortave., 2003; Putz et at, 2004; McDaniel, 2003; Zhang et al., 2000; Shen et al., 2009). Even some studies that show the positive impact of reforms to land tenure in forestry and local economies (Zhang et al., 2002; Changhai et al, 2014; Xie et al, 2013). In Mexico the democratization of natural resources through land reform contributed to the expansion of community forestry (Shelly and Boyce, 2003). Also some studies analyze the impact of agrarian reform 1992 and forest laws in the emergence of CFE and its impact on the consolidation of local institutions in the commons (Bray et al., 2006). 2. Some studies show the form of local self-government of commons, where the role of institutions has been crucial (Ostrom, 1995; Agrawal and Gibson, 1999). 3. Studies of social capital in solving collective action problems (Ahn and Ostrom 2002; Bray et al., 2003; Krishna, 2000). 4. From the business perspective very few studies have examined organizational factors and competitive strategies of the CFE. Studies Donovan et al. (2008); Stoian and Donovan (2010) to community rural enterprises in Latin America, the Caribbean, Asia and Africa which included CFEs found that managed to accumulate physical capital, but show low levels of productivity and quality problems related to the production process. Enterprises also had deficiencies in management skills and technical capabilities of production managers and workers. Some enterprises were undercapitalized regardless of size and scale of production; and in some cases political, legal and regulatory frameworks are impeding the development of enterprises. Further notes that the participation of women in corporate management and decision making is limited. They conclude that most enterprises presented deficiencies financial, social and human capital; however, they showed strengths in natural and physical capital.

It is important to mention that studies Donovan et al. (2008), Stoian and Donovan (2010) did not consider the differences between CFE and private forest 
enterprise, and the potential importance of such differences in performance. Instead the study of Antinori and Bray (2005) shows such differences, in terms of decision control, decision management, legal system, objectives and mainly in land tenure and forest resources, the latter two in CFEs are commonly used (Table 1).

Garibay (2007) argues that CFE in Mexico maintains strict control and planning of forest land, as business efficiency is a function of having extensive wooded land for a long period of time. So, the system of local governance requires villagers to organize devices to care for and make rational use of forest resources. For example, the CFE (UCFAS for its acronym in Spanish) formalized and integrated the logging unit (UNFOSTI for its acronym in Spanish) to ensure adequate extraction, conservation and supply of forest resources (Toledo, 2011).

Table 1 Differences between Mexican CFE and private forest enterprise

\begin{tabular}{|c|c|c|c|c|c|}
\hline \multirow{2}{*}{$\begin{array}{c}\text { Institutional } \\
\text { component }\end{array}$} & \multirow{2}{*}{$\begin{array}{l}\text { No industrial } \\
\text { products } \\
\text { forest }\end{array}$} & \multirow{2}{*}{$\begin{array}{l}\text { Conventional } \\
\text { firm }\end{array}$} & \multicolumn{2}{|c|}{ Cooperatives } & \multirow[t]{2}{*}{ Mexican CFEs } \\
\hline & & & Industrial & Agricultural & \\
\hline Owner(s) & $\begin{array}{l}\text { Individual or } \\
\text { organization }\end{array}$ & $\begin{array}{l}\text { Shareholders, } \\
\text { investors }\end{array}$ & Labor & $\begin{array}{l}\text { Land held } \\
\text { by public, } \\
\text { community } \\
\text { or individual } \\
\text { with sales to } \\
\text { farmer-owned } \\
\text { enterprise }\end{array}$ & $\begin{array}{l}\text { Official members } \\
\text { of the community }\end{array}$ \\
\hline $\begin{array}{l}\text { Decision } \\
\text { management }\end{array}$ & Owner & Managers & $\begin{array}{l}\text { Management } \\
\text { committee } \\
\text { elected by } \\
\text { workers }\end{array}$ & $\begin{array}{l}\text { Management } \\
\text { committee } \\
\text { elected by } \\
\text { producers }\end{array}$ & $\begin{array}{l}\text { Comisariado de } \\
\text { bienes comunales } o \\
\text { ejidales } \\
\text { elected by } \\
\text { members. }\end{array}$ \\
\hline $\begin{array}{l}\text { Decision } \\
\text { control }\end{array}$ & Owner. & $\begin{array}{l}\text { Executive } \\
\text { officers, } \\
\text { shareholders, } \\
\text { auditors }\end{array}$ & $\begin{array}{l}\text { General } \\
\text { Assembly of } \\
\text { workers, } \\
\text { auditors. }\end{array}$ & $\begin{array}{l}\text { General } \\
\text { Assembly } \\
\text { of producers, } \\
\text { auditors }\end{array}$ & $\begin{array}{l}\text { General } \\
\text { Assembly } \\
\text { of local } \\
\text { community } \\
\text { members }\end{array}$ \\
\hline $\begin{array}{l}\text { Legal } \\
\text { system }\end{array}$ & $\begin{array}{l}\text { Land use, tax, } \\
\text { environmental } \\
\text { laws }\end{array}$ & $\begin{array}{l}\text { Land use, } \\
\text { corporate } \\
\text { and tax law }\end{array}$ & $\begin{array}{l}\text { Land use, } \\
\text { corporate } \\
\text { and tax law }\end{array}$ & $\begin{array}{l}\text { National } \\
\text { and state } \\
\text { cooperative } \\
\text { laws. }\end{array}$ & $\begin{array}{l}\text { Agrarian, } \\
\text { forestry, and } \\
\text { environmental } \\
\text { law }\end{array}$ \\
\hline $\begin{array}{l}\text { Objectives, } \\
\text { assumed or } \\
\text { stated }\end{array}$ & $\begin{array}{l}\text { Profit, } \\
\text { amenities, } \\
\text { NTFPs, } \\
\text { bequest }\end{array}$ & $\begin{array}{l}\text { Profit, return } \\
\text { on investment }\end{array}$ & $\begin{array}{l}\text { Dividends } \\
\text { per worker }\end{array}$ & $\begin{array}{l}\text { Unit price, } \\
\text { producer and } \\
\text { consumer } \\
\text { surplus, } \\
\text { services to } \\
\text { members. }\end{array}$ & $\begin{array}{l}\text { Profit, amenities, } \\
\text { NTFPs, bequest, } \\
\text { jobs, public } \\
\text { goods and } \\
\text { services. }\end{array}$ \\
\hline
\end{tabular}

Source: Antinori and Bray (2005).

\subsection{Performance of CFE in Mexico in a scheme of vertical integration \\ 4.2.1 Background of vertical integration}

In the long-term economic performance of the CFE it is key to maintain and expand the market. To do this, the enterprise has to implement competitive strategies with goals in the direction of the government of the commons (Antinori, 2007). The organization of production involves contractual relations with the market, where individuals have to take the decision to make or buy (Coase, 1937; Williamson, 1975). The CFE decides to production through vertical integration. Let us briefly review the origin of vertical integration.
Vertical integration as corporate strategy is rooted in the theory of Bain (1954), within the traditional mainstream of the economy of industrial organization. Bain argues that the firm exists to maximize profits by restricting production. Therefore, justifies the firm implements colluding, strategic alliances, etc., to exercise monopoly power. It assumes that the industry structure determines the behavior of the firm, and therefore influences the performance (Conner, 1991).

Later Coase (1937) points out that the firm is the fundamental basis on which decisions must be made and alternative choices related to the organization of production, which affect the profitability of it. He 
notes that there are two major economic players, the market and the firm, whose relations are realized through contracts in the organization of production. Contractual relationships or transactions that guide the production inside the firm are directed by the coordinator entrepreneur, while transactions that guide the production market are directed by the price mechanism. Coase argues that transaction costs incurred by the firm to guide production either inside the firm or outside the firm are extremely important, affecting production costs and profits.

Williamson (1975) based the transaction costs theory from the contributions of Coase (1937), and defines two types of costs: 1) ex ante associated with finding information about goods, services and people, valuing attributes guiding production to the market, transfer rights and contract negotiation, and 2) generated by ex post monitoring and reviewing the performance of the contract. Williamson (1981) notes that there are three factors that increase transaction costs, 1) frequency of transactions, 2) uncertainty, and 3) asset specificity. Regarding the first, the development continues and monitoring of specific contracts generate high costs; less specific contracts less recurrent generate lower costs for the firm. Uncertainty refers to bounded rationality and opportunistic behavior of agents and asymmetric information in contractual relations. Regarding the third point Williamson (1985) noted that asset specificity is the factor that generates more costs to the firm. This means investment site, physical and human. The specificity of assets can generate high transaction costs, so the firm will have to make the decision to guide production to 1) inside the firm, 2) under a hybrid structure, or 3) outside the firm with the market. Therefore, based on transaction costs the firm will have to make the decision to guide production to the market, or part of the activities under a hybrid relationship or inside the firm. That is, the transaction costs induce vertical integration.

\subsubsection{Vertical integration and performance of the CFE in Mexico}

The activities of producing a good or service is established through the value chain, which is composed by previous and subsequent stages of the main product, ranging from the production of raw materials to the final stage where the good or services is received by the consumer (Porter, 1980).

According to Perry (1989) the enterprise is vertically integrated, whether to produce a single product takes at least two production processes of the value chain, and a part or all of the raw material used as input of the final product. While for Tirole (1989) the enterprise is vertically integrated if it controls all decisions taken by the vertical structure. That is, if it controls the entire production chain. Further he notes that integrating a firm can exercise vertical control over another undertaking depending on the specific active participation in the production chain and dependence of inputs in the production of a final good. In this way, the enterprise can decide only vertically integrate backwards for securing inputs or forward with the marketing of goods or integrated backward and forward in the chain of production (Coase, 1937; Goldma et al., 2003; Alchian, 1995). In order to achieve productive efficiency associated with decreased transaction costs, production costs (economies of scale or scope), administrative costs, control inputs, good quality, facilitate investment and market power (Williamson, 1985; Porter, 1980).

The firm can opt for horizontal integration by the union, fusion, acquisition, joint venture or strategic alliance between two or more firms producing the same product, with the objective of producing efficiently in an enterprise that was occurring possibly inefficiently by two or more firms in a single market (Tirole, 1989). Horizontal integration usually involves firms that were initially competing in the production of a good, while the vertical integration often involves firms that were initially complementary at different stages of production of goods within the same industry (Carlton and Perloff, 2005).

It is important to mention that in addition to the approach of transaction costs analyzing vertical integration, discussed above, is also the perspective of theorists from the new institutional economics explain the forms of government that govern market transactions or into the firm in the allocation of property rights. From this approach, theorists argue that vertical integration is the purchase of assets by a firm to acquire residual rights of control of another firm (Grossman y Hart, 1986; Hart y Moore, 1990). In this respect, vertical integration involves arrangements within the firm that relate to property and, therefore, with the forms of government. Another important element to consider is pointing Mahoney (1992), when it comes to vertical financial ownership or financial control, which is when the firm replaced the financial transfers to the internal market. Another important element to consider is the vertical financial property or financial control, which is when the company replaced the financial transfers to the internal market (Mahoney, 1992). So that vertical integration is implemented through a continuum of governance structures including market, production contracts, joint venture contracts and financial vertical integration.

According to Perry (1989) vertical integration may arises 1) vertical formation; that is, when simultaneously with the creation of the firm, 2) the vertical expansion, when it is a result of business 
growth, creating subsidiaries in neighboring processes; and 3) the fusion, when it is a result of the acquisition of an existing enterprise in a neighboring process.

In Mexico, according Antinori (2000) in addition to the high transaction costs in the market, and the combined effect of three variables: quantity and quality of forest resources, production experience with concessionaires and collective experience in organization increases the likelihood that a community forms a CFE and invests in the most advanced level of the production chain. Considering the contributions of Perry (1989); and findings of Antinori (2000) can be said that vertical integration arises simultaneously with the creation of the CFE. That is, considering that the community had experience in supply of raw material to the concessionary enterprises, collective experience in organizing and natural capital, the community decided to form the CFE and add value to the product, that way the community is involved in transformation processes and marketing which had to develop technical, administrative and management skills. Whose skills evolved to the extent that strengthened each stage of the production chain. Thus the stages of production are vertically integrated under the coordination of the firm. Vertical integration takes shape under a structure of communal government, which defined the property rights of natural resources. Until the point of assuming that the vertical integration strategy of the $\mathrm{CFE}$ is based on the use and control of forest resources to control the production chain, and financial resources (Table 2). Based on the above, this analysis finds that the use and control of forest resources plays a strategic role in the performance of $\mathrm{CFE}$ in Mexico.

Tabla 2 Strategy and performance Mexican CFE

\begin{tabular}{|c|c|c|c|c|c|}
\hline \multirow[t]{2}{*}{ Approach } & \multirow[t]{2}{*}{ Theory } & \multirow{2}{*}{$\begin{array}{c}\text { Performance } \\
\text { private Enterprise }\end{array}$} & \multicolumn{3}{|c|}{ Mexican CFE } \\
\hline & & & Desempeño & Advantage & Disadvantage \\
\hline \multirow{2}{*}{$\begin{array}{l}\text { Strategy } \\
\text { and } \\
\text { sustainable } \\
\text { competitive } \\
\text { advantage }\end{array}$} & $\begin{array}{l}\text { Resources } \\
\text { based view }\end{array}$ & $\begin{array}{l}\text { Intangible } \\
\text { resources: } \\
\text { knowledge }\end{array}$ & $\begin{array}{l}\text { Tangible } \\
\text { resource: } \\
\text { forest } \\
\text { resources }\end{array}$ & $\begin{array}{l}\text { Use and control of forest } \\
\text { resources }\end{array}$ & $\begin{array}{l}\text { Pressure on forest } \\
\text { resources }\end{array}$ \\
\hline & Structuralist & $\begin{array}{l}\text { High barriers to } \\
\text { entry. } \\
\text { Number and size of } \\
\text { enterprises in the } \\
\text { industry. } \\
\text { Product } \\
\text { differentiation. } \\
\text { Vertical } \\
\text { integration. } \\
\text { Concentration of } \\
\text { suppliers. }\end{array}$ & $\begin{array}{l}\text { Vertical } \\
\text { integration }\end{array}$ & $\begin{array}{l}\text { Reducing average } \\
\text { production costs } \\
\text { (economies of scale). } \\
\text { Assurance in supply of } \\
\text { raw material (forest } \\
\text { resources). } \\
\text { Lower priced inputs. } \\
\text { Raise price of forest } \\
\text { resources. } \\
\text { Entry barrier to } \\
\text { competitors. } \\
\text { Concentration of suppliers } \\
\text { of raw materials and other } \\
\text { inputs. } \\
\text { Maintenance niche. }\end{array}$ & $\begin{array}{l}\text { Loss of } \\
\text { competitiveness. } \\
\text { High price } \\
\text { products. } \\
\text { The social } \\
\text { optimum is not } \\
\text { reached. } \\
\text { Poorly } \\
\text { differentiated } \\
\text { product. } \\
\text { Little product } \\
\text { innovation. } \\
\text { Productive } \\
\text { inefficiency } \\
\text { Business } \\
\text { inefficiency. }\end{array}$ \\
\hline $\begin{array}{l}\text { Economics } \\
\text { of industrial } \\
\text { organization }\end{array}$ & $\begin{array}{l}\text { Transaction } \\
\text { costs }\end{array}$ & $\begin{array}{l}\text { Make production } \\
\text { inside firm } \\
\text { (vertical } \\
\text { integration). } \\
\text { Make production } \\
\text { inside firm and } \\
\text { outside firm with } \\
\text { market. } \\
\text { Make production } \\
\text { outside firm with } \\
\text { market }\end{array}$ & $\begin{array}{l}\text { Make } \\
\text { production } \\
\text { inside firm } \\
\text { (vertical } \\
\text { integration). }\end{array}$ & $\begin{array}{l}\text { In business units: cost } \\
\text { reduction negotiation and } \\
\text { monitoring compliance } \\
\text { with contracts. } \\
\text { Reducing information } \\
\text { asymmetries and conflicts. } \\
\text { Reducing opportunism. } \\
\text { Specific asset } \\
\text { management (site, } \\
\text { physical and human). }\end{array}$ & $\begin{array}{l}\text { Investment } \\
\text { specific assets } \\
\text { (site, physical, and } \\
\text { human). } \\
\text { Increased costs of } \\
\text { coordination and } \\
\text { monitoring, by } \\
\text { establishing rules } \\
\text { of conduct and } \\
\text { efficiency } \\
\text { practices inside } \\
\text { firm. }\end{array}$ \\
\hline
\end{tabular}


The Role of Forest Resources in the Performance of Community Forest Enterprise in Mexico: Analytical Framework from Competitive Strategy

\begin{tabular}{|c|c|c|c|c|c|}
\hline $\begin{array}{l}\text { New } \\
\text { institutional } \\
\text { economics }\end{array}$ & $\begin{array}{l}\text { Common- } \\
\text { pool } \\
\text { resources }\end{array}$ & $\begin{array}{l}\text { Institutions. } \\
\text { Property rights }\end{array}$ & $\begin{array}{l}\text { Institutions } \\
\text { of the } \\
\text { commons. } \\
\text { Communal } \\
\text { property } \\
\text { rights. } \\
\text { Long-term } \\
\text { principles of } \\
\text { common } \\
\text { resources. }\end{array}$ & $\begin{array}{l}\text { Institutional capital } \\
\text { (governance system). } \\
\text { Right to use (access, } \\
\text { extraction), and control of } \\
\text { forest resources } \\
\text { (management, exclusion } \\
\text { and alienation). } \\
\text { Social capital. } \\
\text { Natural capital. } \\
\text { Diversification of } \\
\text { production. }\end{array}$ & $\begin{array}{l}\text { Over-regulation of } \\
\text { natural resources. } \\
\text { Centralized } \\
\text { territorial control. } \\
\text { Hierarchical } \\
\text { control. } \\
\text { Autocratic control. }\end{array}$ \\
\hline & $\begin{array}{l}\text { Structures } \\
\text { of } \\
\text { government }\end{array}$ & $\begin{array}{l}\text { Institutions. } \\
\text { Property rights. } \\
\text { Purchase of assets } \\
\text { and residual rights. } \\
\text { Financial control. }\end{array}$ & $\begin{array}{l}\text { Institutions. } \\
\text { Property } \\
\text { rights. } \\
\text { Financial } \\
\text { control. }\end{array}$ & $\begin{array}{l}\text { Share risk. } \\
\text { Domestic investment. } \\
\text { Equitable distribution of } \\
\text { profits. } \\
\text { Diversification of profits. }\end{array}$ & $\begin{array}{l}\text { No foreign } \\
\text { investment. } \\
\text { Dependence on } \\
\text { domestic financial } \\
\text { resources. }\end{array}$ \\
\hline
\end{tabular}

Source: Elaboration based Bain (1954); Porter (1980); Tirole (1989); Barney (1991); Coase (1937); Williamson (1975); Grossman and Hart (1986); Hart and Moore (1990); and Mahoney (1992).

\section{Conclusion}

The study of Antinori and Bray (2005) highlight the differences between CFE and private forest enterprise in Mexico, has a strict governance system and property rights. From which it takes shape the organizational structure and objectives of the enterprise. In private enterprise organizational structure that manages production it is defined by the owner, partners or shareholders with individual contributions of capital with the objective of maximizing and distribution of benefits depending on contributions. In the CFE organizational structure for production it is defined by a system traditional positions and an enterprise system, with multiple objectives, as well as economic, are social and environmental (Bray et al., 2006; Garibay, 2007). The objective of the enterprise dictates the strategy to follow to enter, stay or expand the market. In light of the theories of the firm discussed in this work, the firm's competitive strategy defined from a combination of intangible resources (valuable, rare, imperfectly imitable and replaceable), and tangible resources (physical, site, technology, etc.) (Barney, 1991); and engages in business schemes to reduce transaction costs, production costs in general, or to improve or develop new products (Coase, 1937; Williamson, 1975; Porter, 1980). So it decides integrate vertically or horizontally or disintegrates into a framework of governance structures and property rights and arrangements that enable exchanges between the two economic agents, market and firm (Tirole; 1989; Hart y Moore, 1990). To maintain and expand the market the Mexican CFE competitive strategy based mainly on the forest resource and engages simultaneously in vertical integration in as they mature management capabilities and overall production (Perry, 1989). The multiple objectives of the $\mathrm{CFE}$ in the same direction government of the commons, consistent with the property rights make the maximization and distribution of economic benefits is not the only objective, there are also social and environmental objectives to meet. From this point of view the performance of the CFE is seen as positive because the enterprise are not only profitable in the domestic market, but the distribution of benefits to members and community contribute to poverty reduction and management of resources natural to care for the environment (Antinori, 2000; Antinori y Bray, 2005; Villavicencio, 2012). However, based on the analysis it can be displayed that some implications as a result of the strategy followed by the CFE and which should be considered as pressure on forest resources, over-regulation of natural resources, individuals do not achieve the social optimum for prices high product. Therefore high risk domestic markets and that leads to the loss of competitiveness internationally. Given these challenges, this analysis opens up a range of ideas, proposals, discussions, questions and hypotheses for the followers of the new institutional economics and theories of the firm. Perhaps we are on the threshold of the theory of the firm based on common-pool resources.

\section{References}

1) Agrawal, A., Gibson, C. C., 1999. Enchantment and disenchantment: The role of community in natural resource conservation. World Development, 27(4), 629-649. http://dx.doi.org/10.1016/s0305-750x(98)00161-2

2) Ahn, T. K., Ostrom, E., 2002. Social capital and the second generation theories of collective action: An analytical approach to the forms of social capital, Annual Meeting of the American Political Science Association, Boston, Massachusetts, USA.

3) Alchian, A. A., 1995. Vertical integration and regulation in the telephone industry. Managerial and Decision Economics, Vol. 16. 323. http://dx.doi.org/10.1002/mde.4090160406

4) Antinori, C. M., 2000. Vertical integration in Mexican common property forests. Unpublished Ph.D. Dissertation, Department of Agricultural Economics, University of California, Berkeley.

5) Antinori, C. M., Bray, D. B., 2005. Community forest enterprises as entrepreneurial firms: economic and institutional perspectives from México. World Development, 
33

http://dx.doi.org/10.1016/j.worlddev.2004.10.011

(9),1529-1543

6) Antinori, C., 2007. Integración vertical en las empresas forestales comunitarias de Oaxaca. In Bray, D., Merino, L., Barry, D. (eds.). Los bosques comunitarios de México: manejo sustentable de paisajes forestales. 303-342.

7) Azqueta, D., Ferreiro, A., 1994. Análisis económico y gestión de los recursos naturales. Alianza Económica. Madrid.

8) Bain, J., 1954. Economics of scale, concentration, and the conditions of entry in twenty manufacturing industries. American Economic Review, 44, 15-34.

9) Barney, J., 1986, Strategic factor markets: Expectations, luck, and business strategy, Management Science, 32 (10), 656-665. http://dx.doi.org/10.1287/mnsc.32.10.1231

10) Barney, J., 1991, Firm resources and sustained competitive advantage, Journal of Management, 17 (1), 99-120. http://dx.doi.org/10.1177/014920639101700108

11) Boyce, J. K., Shelly, B. G., 2003. Natural assets: Democratizing environmental ownership. Washington, DC: Island Press.

12) Burger, J., Ostrom, E., Norgaard, R., Policansky, D., Goldstein, B., 2001. Reformulating the commons. En protecting the commons: a framework for resource management in the Americas, Washington, D. C., Island Press, 17-41. http://dx.doi.org/10.1017/s0376892902300079

13) Bray, D. B., Merino Pérez, L., Negreros-Castillo, P., SeguraWarnholtz, G., Torres-Rojo, J.M., Vester, H. F. M., 2003. Mexico's community-managed forests as a global model for sustainable landscapes. Conservation Biology 17 (3), 672 677. http://dx.doi.org/10.1046/j.1523-1739.2003.01639.x

14) Bray, D.B., Merino-Pérez, L., 2004. La experiencia de las comunidades forestales en México: Veinticinco años de silvicultura y construcción de empresas comunitarias. Instituto Nacional de Ecología (INI-SEMARNAT), México City.

15) Bray, D., Antinori, C., Torres-Rojo, J., 2006. The Mexican model of community forest management. Forest Policy and Economics. $\quad 8, \quad 470-484$. http://dx.doi.org/10.1016/j.forpol.2005.08.002

16) Brush, C., Chaganti, R., 1998. Businesses without glamour? An analysis of resources on performance by size and age in small service and retail firms, Journal of Business Venturing, $14, \quad 233-257 . \quad$ http://dx.doi.org/10.1016/s08839026(97)00103-1

17) Carlton, D., Perloff, J., 2005. Modern industrial organization. Addison-Wesley. http://dx.doi.org/10.1093/ajae/83.1.254

18) Changhai, W., Wen, Y., Jing, W., 2014. The socio-economic effect of the reform of the collective forest rights system in Suthern China: A case of Tonggu County, Jiangxi Province.Small-scale Forestry, Published online: doi:10.1007/s11842-014-9263-9. http://dx.doi.org/10.1007/s11842-014-9263-9

19) Coase, R. H., 1937. The nature of the firm, Economica, 4 386-405. 0335.1937.tb00002.x

20) Coase, R. H., 1960. The problem of social cost, Journal of Law and Economics, 3(1), 1-44. http://dx.doi.org/10.1086/466560

21) Coloma, G. (2002). Industrial organization notes (part 1). Working paper, 221, 1- 96.

22) Coloma, G. (2002). ). Industrial organization notes (part 2). Working paper 222, 1-89.

23) Comisión Nacional Forestal (CONAFOR), 2012. Tenencia forestal y silvicultura comunitaria en México. Available in $\langle$ http://www.conafor. gob.mx>.

24) Comisión Nacional Forestal (CONAFOR), 2013. Logros y perspectivas del desarrollo forestal en México 2007-2012. Coordinación general de producción y productividad. 1-56.

25) Cortave, M., 2003. La experiencia de ACOFOP en Petén, Guatemala: un proceso arduo de gestión política. Centro de Derecho Ambiental y de los Recursos Naturales/Coordinadora Indígena-Campesina de Agroforesteria Comunitaria. San José Costa Rica.
26) Clark, C. W., 1990. Mathematical bioeconomics: The optimal control of renewable Resources, Wiley Intersicence.

27) Cubbage, F., Davis, R., Rodriguez, D., Frey, G., Mollenhauer, R., Kraus, Y., González, I., Albarrán, H., Salazar, A., Chemor, D., 2013. Competitividad y acceso a mercados de empresas forestales comunitarias en México. PROFOR. 1-124.

28) Chapela, F., Lara, Y., 1995. El papel de las comunidades campesinas en la conservación de los bosques. México, Consejo Civil Mexicano para la Silvicultura Sostenible/Era.

29) Donovan, J., Stoian, D., Poole, N., 2008. Global review of rural community enterprises: The long and winding road to creating viable businesses and potential shortcuts. Technical Series. No. 29. CATIE. Turrialba, Costa Rica.

30) Garibay, C., 2007. El dilema corporativo del comunalismo forestal. Descatos, 23, 251-274.

31) Goldman, C., Goshs, I., Piaskoski, M., 2003. The role of efficiencies in telecomunications merger review. Federal Communications Law Journal.

32) Grant, R., 1991. The resource-based theory of competitive advantage: Implications for strategy formulation. California Management Review, 33(3), 114-135. http://dx.doi.org/10.2307/41166664

33) Grossmam, S., Hart, O., 1986. The cost and benefits of ownership: A theory of vertical and lateral integration, Journal of Political Economy 94, 691-719. http://dx.doi.org/10.1086/261404

34) Hall, R., 1992. The strategy analysis of intagible resources. Strategic Management Journal, 13 (2), 135-144. http://dx.doi.org/10.1002/smj.4250130205

35) Hall, R., 1993. A framework linking intangible resources and capabilities to sustainable competitive advantage. Strategic $\begin{array}{llll}\text { Management Journal, } 14 \text { (8), 607-618. } & \text {. }\end{array}$ http://dx.doi.org/10.1002/smj.4250140804

36) Hall, M., Weiss, L., 1967. Firm size and profitability. Review of Economics and Statistics, 49 (8), 319-331 http://dx.doi.org/10.2307/1926642

37) Hart, O., Moore,J., 1990. Property rights and the theory of the firm, Journal of Political Economy, 98, 1119-1158. http://dx.doi.org/10.1086/261729

38) Hawawini, G., Subramanian, V., y Verdin, P., 2003. Is performance driven by industry-or firm-specific factors? A new look at the evidence. Strategic management Journal, 24, 1-16. http://dx.doi.org/10.1002/smj.278

39) Hansen, G., Wernerfelt, B., 1989. Determinants of firm performance: The relative importance of economic and organizational factors. Strategic Management Journal, 10 (5), 399-411. http://dx.doi.org/10.1002/smj.4250100502

40) Hardin, G., 1968. The tragedy of the commons. Science, 62, 1243-48. http://dx.doi.org/10.1126/science.162.3859.1243

41) Food and Agriculture Organization (FAO), 2006. Tendencias y perspectivas del sector forestal en América Latina y el Caribe. 1-178

42) Food and Agriculture Organization (FAO), 2010. Global forest resource assessment. Forestry Paper, 163. 340.

43) Hatch, N., Dyer, J., 2004. Human capital and learning as a source of sustainable competitive advantage. Strategic Management Journal, 25, 1155-1178. http://dx.doi.org/10.1002/smj.421

44) Krishna, A., 2000. Creating and harnessing social capital. In: Dasgupta, P., Serageldin, I. (Eds.), Social Capital: A multifaceted perspective. World Bank, Washington, D.C., 71-93. http://dx.doi.org/10.1177/08969205000260030801

45) Ley, Agraria, 2002. Anaya Editores, Mexico City.

46) Mahoney, J., 1992. The choice of organizational form: Vertical financial ownership versus other methods of vertical integration. Strategic Management Journal 13 (8), 559-584. http://dx.doi.org/10.1002/smj.4250130802

47) Mahoney, J., Pandian, R., 1992. The resource-based view within the conversation of strategic management. Strategic Management Journal, 13 (5), 363-380 http://dx.doi.org/10.1002/smj.4250130505

48) Mauri, A., Michaels, P., 1998. Firm an industry effects within strategic management: An empirical examination. Strategic 
Management Journal, 19

(3), 211-219. http://dx.doi.org/10.1002/(sici)1097-

0266(199803)19:3\%3C211::aid-smj947\%3E3.0.co;2-t

49) Merino, P. L., Segura-Warnholtz, G., 2005. Forest and conservation policies and their impacts on forest communities in Mexico. In Bray, D. B., Merino, P. L., Barry, D., (Eds), The community forests of Mexico: Managing for Sustainable Landscapes, Austin, Texas, University of Texas Press. http://dx.doi.org/10.1007/s10745-006-9073-6

50) Miller, D., 2004. Firm's technological resources and the performance effects of diversification: A longitudinal study. Strategic Management Journal, 25, 1097-1119. http://dx.doi.org/10.1002/smj.411

51) Muñoz-Piña, C., de Janvry, A., Sadoulet, E., 2003. Recrafting rights over common property resources in Mexico: Divide, incorporate, and equalize. Economic Development and $\begin{array}{lllll}\text { Cultural } & \text { Change, } & 52 & \text { (1), 129-158. }\end{array}$ http://dx.doi.org/10.1086/380104

52) McDaniel, J.M., 2003. Community-based forestry and timber certification in southeast Bolivia. Small-scale Forest. Economics, Management and Policy 2 (3), 327-341.

53) McEvily, S., Chakravarthy, B., 2002. The perspective of knowledge-based advantage: An empirical test for product performance and technological knowledge. Strategic Management Journal, 23, 285-305. http://dx.doi.org/10.1002/smj.223

54) McGahan, A., Porter, M., 1997. How much industry matter, really? Strategic Management Journal, 18, 15-30. http://dx.doi.org/10.1002/(sici)1097-

0266(199707)18:1+\%3C15::aid-smj916\%3E3.3.co;2-t

55) Nolan, T., M., 2001. Community based forest management: Commercial harvesting of the rainforest of Indonesia. The International Forestry Review, 3 (3), 231-235.

56) North, D. C., 1990. Institutions, institutional change and economic performance. Cambridge University Press. Cambridge. http://dx.doi.org/10.1017/s0022050700040493

57) Ostrom, E., 1990. Governing the commons. Cambridge University Press, Cambridge. http://dx.doi.org/10.1007/s11615-002-0044-2

58) Ostrom, E., 1995. Self-organization and social capital. Industrial and Corporate Change, 4(1), 131-159. http://dx.doi.org/10.1093/icc/4.1.131

59) Pearce, D. W., Turner, R. K., 1990. Economics of natural resources and the environment. The John Hopkins University Press.

60) Penrose, E., 1959. The theory of the growth of the firm. Oxford University Press. Oxford.

61) Perry, M., 1989. Vertical Integration. Determinants and effects in: Schmalensee, R., Willing, R. (Eds), Handbook of Industrial Organization, 1, Amsterdam, North-Holland.

62) Porter, M., 1980. Competitive Strategy: Techniques for analysing industries and competitors. Free Press: New York.

63) Porter, M., 1985. Competitive Advantage: Creating and sustaining superior performance. New York: Free Press. http://dx.doi.org/10.1590/s0034-75901985000200009

64) Putz, F. E., Pinard, M. A., Fredericksen, T.S., Peña-Claros, M., 2004. Forest science and the BOLFOR experience: Lessons learned about natural forest management in Bolivia. In: Zarin, D., Alavapati, J. R. R., Putz, F. E., Schmink, M., (Eds.), working forests in the neotropics: Conservation through sustainable management? Columbia University Press, New York, 64-96.

65) Prescott, J., Kohli, A., Venkataraman, N., 1986. The market share-profitability relationship: an empirical assessment of major assertions and contradictions. Strategic Management $\begin{array}{llll}\text { Journal, } & 7 & \text { (4), } & 377-394 .\end{array}$ http://dx.doi.org/10.1002/smj.4250070407

66) Rumelt, R., 1991. How much industry matter? Strategic management Journal, 12, 167-185. http://dx.doi.org/10.1002/smj.4250120302

67) Segura-Warnholtz, G., 2014. Quince años de políticas públicas para la acción colectiva en comunidades forestales. Revista Mexicana de Sociología, 76 (5),105-135.
68) Schlager E., Ostrom, E., 1992. Property rights regimes and natural resources. A conceptual analysis. Land Economics, 68 (3), 249-262. http://dx.doi.org/10.2307/3146375

69) Scherr, S. J., White, A., Kaimowitz, D., 2003. A new agenda for conservation and poverty reduction: Making forest markets work for low-income producers. Washington, DC Forest Trends/Center for International Forestry Research. http://dx.doi.org/10.1017/s0030605305240188

70) Schroeder, R., Bates, K., Juntila, M., 2002. A resource-based view of manufacturing strategy and the relationship to manufacturing performance. Strategic Management Journal, 23, 105-117. http://dx.doi.org/10.1002/smj.213

71) Shen, Y., Zhang, Y., Xu, X., Zhu, Z., Jiang, X., 2009. Towards decentralization and privatization of China's collective forestlands. International Forestry Review, 11 (4), 28-35. http://dx.doi.org/10.1505/ifor.11.4.456

72) Schmalensee, R., 1985. Do markets differ much. The American Economic Review, 75, 341-350.

73) Schmalensee, R., Willing, R., 1992. Handbook of industrial organization. $\quad 1, \quad$ North-Holland. http://dx.doi.org/10.1002/mde.4090130209

74) Stoian, D., Donovan, J., 2010. Poverty-environment dividends of rural community enterprises: insights from a cross-sectorial study in Latin America and the Caribbean. Tropical Agricultural Research and Higher Education Center (CATIE). Program competitiveness and value chains Center for Competitiveness of Ecoenterprises (CeCoEco).

75) Tirole, J., 1989. The theory of industrial organization, Cambridge, MIT Press. http://dx.doi.org/10.1002/mde.4090110207

76) Toledo, H. E., 2012. Instituciones e integración vertical de las empresas forestales comunitarias de productos maderables de Oaxaca: Caso ICOFOSA. Tesis de maestría. IPN. Mexico.

77) Villavicencio, G., Hansen, R., Bliss, J., 2012. Factors impacting marketplace success of community forest enterprises: The case of TIP muebles, Oaxaca, Mexico. Small-scale Forestry. Published online: doi 10.1007/s11842 011-9188-5. http://dx.doi.org/10.1007/s11842-011-9188-5

78) Wernerfelt, B., 1984. A resource-based view of the firm. Strategic Management Journal, 5 (2), 171-180 http://dx.doi.org/10.1002/smj.4250050207

79) Williamson, O. E., 1975. Markets and hierarchies: analysis and antitrust implications. Free Press, New York.

80) Williamson, O. E., 1981. The economics of organizations: the transaction cost approach. The American Journal of Sociology, 87 (3), 548-577. http://dx.doi.org/10.1086/227496

81) Williamson, O. E., 1985. The economics institutions of capitalism: firms, markets, relational contracting. Free Press, New York. http://dx.doi.org/10.2307/135384

82) Wilshusen, P. R., 2003. Negotiating devolution: Community conflict, structural power, and local forest management in Quintana Roo, Mexico. University of Michigan, School of Natural Resources and Environment, Ann Arbor.

83) White, A., Martin, A., 2002. Who owns the world's forests? Washington, DC: Forest Trends. Center for International Law.

84) Xie, Y., Wen, Y., Zhang, Y., Li, X., 2013. Impact of property rights reform on household forest management investment: An empirical study of southern China. Forest Policy and Economics 34, 73-78. http://dx.doi.org/10.1016/j.forpol.2012.12.002

85) Yli-Renko, H., Autio., E., Sapienza, J., 2001. Social capital, knowledge acquisition, and knowledge exploitation in young technology-based firms. Strategic Management Journal, 22, 587-613. http://dx.doi.org/10.1002/smj.183

86) Zhang, Y., Uusivuori, J., Kuuluvainen, J., 2000. Impacts of economic reforms on rural forestry in China. Forest Policy and Economics 1 (1), 27-40. http://dx.doi.org/10.1016/s1389-9341(00)00007-1

87) Zhang, Y., 2002. The Impacts of economic reforms on the efficiency of silviculture: A non-parametric approach. Environment and Development Economics 7 (1), 107-122. http://dx.doi.org/10.1017/s1355770x02000062 